Research article

\title{
Evaluation of hybrids Sorghum (Sorghum bicolor L. Moench.) for growth and yield in a rainforest agro-ecological zone
}

\author{
A. O. Eniola*, A. C. Odiyi, L. S. Fayeun and A. B. Obilana \\ Department of Crop, Soil and Pest Management, School of Agriculture and Agricultural Technology, Federal \\ University of Technology, PMB 704, Akure, Ondo State, Nigeria
}

*Corresponding Author: deniola2000@yahoo.com

[Accepted: 19 December 2019]

\begin{abstract}
A field experiment was carried out during 2016 and 2017 cropping seasons at the Teaching and Research Farm of The Federal University of Technology, Akure with the aim of evaluating growth and yield performance of twenty-five hybrids sorghum. The experiment was laid out in a randomised complete block design with three replications. Data collected on seedling emergence count, number of days to $50 \%$ flowering, number of days to $95 \%$ maturity, plant height $(\mathrm{cm})$, panicle length $(\mathrm{cm})$, panicle diameter $(\mathrm{cm})$, panicle weight $(\mathrm{g})$, 1000-grain weight $(\mathrm{g})$, number of seeds per panicle and grain yield (kg ha-1) were subjected to analysis of variance. The hybrids differed $(\mathrm{p} \leq 0.05$ and $\mathrm{p} \leq 0.01)$ for all the traits except seedling emergence count. Estimates of variance component, broad-sense heritability, correlation analysis and rank summation index (RSI) were computed. High genetic advance (689.64 and 433.13) accompanied moderate heritability for number of seeds per panicle and grain yield respectively. Panicle length had positive and significant correlation with panicle weight, panicle diameter, number of seeds per panicle and grain yield $(r=0.36,0.57,0.27$ and 0.36 , respectively). Panicle weight had negative and significant correlation with 1000 -grain weight $(\mathrm{r}=-0.32)$ but positive correlations was recorded in panicle diameter, number of seeds per panicle and grain yield $(\mathrm{r}=0.38,0.89$ and 0.98$)$. Nevertheless, number of seeds per panicle had positive significant correlation with grain yield $(\mathrm{r}=$ $0.84)$. RSI showed that hybrid ICSA $38 \times$ ICSV 400 had the best performance with a mean rank of (4.8) and followed by ICSA38 $\times$ PIRIRA-2-1 with a mean rank of (6.6). Hence, due consideration should be given to these characters; panicle length, panicle weight and number of seeds per panicle while planning a breeding strategy for increased sorghum grain yield.
\end{abstract}

Keywords: Hybrid - Variation - Correlation - Rank Summation Index.

[Cite as: Eniola AO, Odiyi AC, Fayeun LS \& Obilana AB (2019) Evaluation of hybrids Sorghum (Sorghum bicolor L. Moench.) for growth and yield in a rainforest agro-ecological zone. Tropical Plant Research 6(3): 497-505]

\section{INTRODUCTION}

Sorghum (Sorghum bicolor L. Moench.) occupies a prominent position in global agriculture after wheat, rice and maize (FAO 2004). It constitutes the main grain food for over 750 million people who live in the semi-arid tropics of Africa, Asia and Latin America (FAO 2004). Major producers of sorghum in the world are USA, Nigeria, India, China, Mexico, Sudan and Argentina (USDA 2017). It has gained importance for its grain, fodder and stalk in developing countries, while in developed countries the crop is used primarily as animal feed (Obilana 2004). Sorghum as food could improve nourishment, as the air-dried whole grain sorghum contains approximately $8-19 \%$ moisture, $68-74 \%$ carbohydrates, $8-15 \%$ protein, $2-5 \%$ fats, $1-3 \%$ fibre and $1.5-2.0 \%$ ash Dasai et al. (1992). Industrially, grain sorghum is used in the production of flour, alcoholic, malted beverages, vegetable oil, adhesives, waxes, dyes, sizing for paper and cloth, are just some of the products that could be obtained (Obilana 2004, Paterson 2009). In developing countries particularly in West Africa, demand for sorghum is increasing (FAO 2010). This is due to not only to the growing population, but also to the countries' policy to enhance their processing and industrial utilization (Akintayo \& Sedgo 2003). The ultimate goal is to enhance sorghum production efficiency and make good use of new economic opportunity in the 
brewing, non-alcoholic beverages and weaning foods industries, which are offered today to sorghum growers (Obilana 2004). In Nigeria, sorghum is the most widely cultivated staple cereal crop across the agro-ecological zones, the Sahel, Sudan, and Guinea savannas contributed $99 \%$ and the remaining $1 \%$ is grown in the derived savanna zone of southwestern (FMARD 2011). Climate change is affecting the above-mentioned zones, desert encroachment and insurgency issues (Boko Haram) threaten crop production with high sorghum production percentage (FMARD 2011, Mohammed \& Ahmed 2015, Alade et al. 2017). There is a need to investigate the potential of hybrid sorghum production in the rainforest in order to provide information on adaptation of the selected hybrids to southwest agro-ecological zone which will eventually increase sorghum production in Nigeria. Correlation coefficients show associations among independent characteristics and the degree of linear relation between these characteristics while path analysis takes into account the cause and effect relationship between the variables by partitioning the association into direct and indirect effects through other independent variables (Mohammed \& Talib 2008). Therefore, this work was initiated to evaluate growth and yield performance among some sorghum hybrids and determine relationship between yield and related characters.

\section{MATERIALS AND METHODS}

The experiment was conducted at the Teaching and Research Farm, Federal University of Technology, Akure (FUTA); a tropical rainforest zone of southwestern Nigeria. It lies at an altitude of $332 \mathrm{~m}$ above sea level, between longitude $5^{\circ} 06^{\prime} \mathrm{E}$ to $5^{\circ} 38^{\prime} \mathrm{E}$ and between latitude $7^{\circ} 07^{\prime} \mathrm{N}$ to $7^{\circ} 37^{\prime} \mathrm{N}$ in rainforest south-western Nigeria (Ayeni 2011). The study location is characterized by bimodal pattern of rainfall with an annual mean of about $1542 \mathrm{~mm}$ with a mean temperature of $27^{\circ} \mathrm{C}$ (Ayeni 2011).

The experiment was laid out in a randomised complete block design with three replications. The plot size was 2-row plots measuring $5 \mathrm{~m}$ each. Spacing was $25 \mathrm{~cm}$ (intra-row) $\times 75 \mathrm{~cm}$ (inter-row). The plantings were done on $4^{\text {th }}$ August, 2016 and $28^{\text {th }}$ July, 2017 for the first and second year respectively. Five seeds were planted per hole. Thinning was done where necessary at 2-3 weeks after planting to obtain plant population. Hand weeding was also done when necessary to keep the field weed-free. NPK fertilizer (15:15:15) was applied at the rate of $\left(60 \mathrm{~kg} \mathrm{ha}^{-1} \mathrm{~N}, 30 \mathrm{~kg} \mathrm{ha}^{-1} \mathrm{P}_{2} \mathrm{O}_{5}\right.$ and $\left.30 \mathrm{~kg} \mathrm{ha}^{-1} \mathrm{~K}_{2} \mathrm{O}\right)$ at 3 weeks after planting. Urea $\left(60 \mathrm{~kg} \mathrm{ha}^{-1}\right)$ was applied as top dressing at nine weeks after planting. Method of IPGRI (1993) was adopted for sorghum data collection. In each plot, the five middle rows were used to measure the following agronomic characters:

a. Seedling emergence count: The number of emerged seedlings per plot was counted and recorded after 7 days of planting.

b. Number of days to $\mathbf{5 0 \%}$ flowering: The number of days from the sowing date to the day on which $50 \%$ of the plants in a plot flowered.

c. Number of days to $95 \%$ maturity: The number of days from sowing date to the number of days on which $95 \%$ of the panicles in a plot reached physiological maturity, as monitored by the appearance of black glumes kernels.

d. Plant height at harvest: The average of the lengths of five randomly selected plants (each measured from the ground to the tip of the panicle in centimetres).

e. Panicle length: The average length of a panicle from the base of the panicle to the tip of a panicle from five randomly selected plants in a plot and measured in centimetres.

f. Panicle diameter: The average width of a panicle from the main stem measured at the widest part of the panicle from five randomly selected plants in a plot and measured in centimetres.

g. Panicle weight: The average weight of main panicle from five randomly selected plants in a plot and measured in gramme.

h. 1000-grain weight: The weight of 1000 grains was obtained by weighing samples of 1000 filled grains using electronic balance and measured in gramme.

i. Number of seeds per panicle: The number of seeds counted from main panicles of five randomly selected plants in a plot.

j. Grain yield: The weight of harvested grain per plot, expressed in kilograms per hectare $\left(\mathrm{kg} \mathrm{ha}^{-1}\right)$.

The data collected were subjected to analysis of variance using the MINITAB packaged (Version 17 software) and significant mean were separated using Tukey's test. PB tools (Version 1.4 software) were used to analyse genotypic and phenotypic correlation.

Phenotypic and genotypic coefficients of variation were computed using the procedure of (Singh \& Chaudhury 1985) as follows. 


$$
\begin{aligned}
& \text { Genotypic coefficient of variation }(\mathrm{GCV})=\frac{\sqrt{\sigma^{2}} \mathrm{~g}}{\overline{\mathrm{x}}} \times 100 \\
& \text { Phenotypic coefficient of variation }(\mathrm{PCV})=\frac{\sqrt{\sigma^{2}} \mathrm{p}}{\overline{\mathrm{x}}} \times 100
\end{aligned}
$$

GCV and PCV values were categorized as low, moderate and high (Siva-Subramanian \& Menon 1973).

$$
\begin{aligned}
& 0-10 \%: \text { Low } \\
& 10-20 \%: \text { Moderate } \\
& 21 \% \text { and above: High }
\end{aligned}
$$

Broad sense heritability was estimated as the ratio of genetic variance to the phenotypic variance and expressed in percentage as recommended by (Singh \& Chaudhury 1985):

Where, $\sigma^{2} \mathrm{~g}+\sigma^{2} \mathrm{e}=\sigma^{2} \mathrm{p}$

$$
\text { Heritability }(\mathrm{H})=\frac{\sigma^{2} \mathrm{~g}}{\sigma^{2} \mathrm{~g}+\sigma^{2} \mathrm{e}} \times 100
$$

Heritability percentage was categorized as low, moderate and high as by (Elrod \& Stanfield 2002) as follows:

$$
\begin{aligned}
& 0-20 \%: \text { Low } \\
& 20-50 \%: \text { Moderate } \\
& 50 \% \text { and above: High }
\end{aligned}
$$

Genetic advance (GA) was computed according to the formula given by Johnson et al. (1955) as used by Fayeun et al. (2012).

$$
\mathrm{GA}=\frac{\sigma^{2} \mathrm{~g}}{\sqrt{\sigma^{2} \mathrm{p}}} \times \mathrm{K}
$$

Where, $K=2.06$ (selection differential at $5 \%$ ); $\sigma^{2} \mathrm{~g}=$ Genotypic variation; $\sigma^{2} \mathrm{p}=$ Phenotypic variation; $\overline{\mathrm{x}}=$ Sample mean of the character

Correlation coefficients were calculated to determine the degree of association among the characters. This was done according to the formula suggested by (Singh \& Chaudhury 1985).

$$
r_{x y}=\frac{\operatorname{COV}_{x y}}{\sqrt{\operatorname{var}_{x} \operatorname{Var}_{y}}}
$$

Where, $r_{x y}=$ correlation coefficient between character $\mathrm{x}$ and $\mathrm{y} ; \operatorname{COV}_{(x y)}=$ covariance of character $\mathrm{x}$ and $\mathrm{y}$; $\operatorname{Var}_{x}=$ variance of character $\mathrm{x} ; \operatorname{Var}_{y}=$ variance of character $\mathrm{y}$.

\begin{tabular}{|c|c|c|c|c|c|c|c|c|c|c|c|}
\hline \multirow[b]{2}{*}{$\begin{array}{l}\text { Source of } \\
\text { variation }\end{array}$} & \multicolumn{11}{|c|}{ Characters } \\
\hline & DF & $\begin{array}{r}\text { Seedling } \\
\text { emergence } \\
\text { count }\end{array}$ & $\begin{array}{r}\text { Days to } \\
50 \% \\
\text { flowering }\end{array}$ & $\begin{array}{r}\text { Days to } \\
95 \% \\
\text { maturity } \\
\end{array}$ & $\begin{array}{r}\text { Plant } \\
\text { height } \\
(\mathrm{cm})\end{array}$ & $\begin{array}{r}\text { Panicle } \\
\text { length } \\
(\mathrm{cm})\end{array}$ & $\begin{array}{r}\text { Panicle } \\
\text { weight } \\
\text { (g) }\end{array}$ & $\begin{array}{r}\text { 1000-grain } \\
\text { weight } \\
(\mathrm{g})\end{array}$ & $\begin{array}{r}\text { Panicle } \\
\text { diameter } \\
(\mathrm{cm})\end{array}$ & $\begin{array}{r}\text { Number of } \\
\text { seeds per } \\
\text { panicle }\end{array}$ & $\begin{array}{r}\text { Grain } \\
\text { Yield } \\
\left(\mathrm{kg} \mathrm{ha}^{-1}\right)\end{array}$ \\
\hline Replicates & 2 & 69.147 & 21.140 & 56.720 & 577.62 & 29.4261 & 358.88 & 120.327 & 2.18502 & 1308702 & 322994 \\
\hline Year & 1 & 0.427 & 1.127 & 1.927 & 21.28 & 0.0216 & 0.20 & 0.325 & 0.02587 & 16203 & 182 \\
\hline Hybrids & 24 & 251.226 & $50.096^{*}$ & $40.790 * *$ & $9372.34 * *$ & $36.4163 * *$ & $1813.17 * *$ & $70.578 * *$ & $2.05013 * *$ & $6083746^{* *}$ & $1631852 * *$ \\
\hline Hybrids*Years & 24 & 8.857 & 10.043 & 2.093 & 2.75 & $0.0878 * *$ & 1.23 & $0.463 * *$ & 0.01376 & 18105 & 1111 \\
\hline Error & 98 & 43.290 & 21.242 & 7.917 & 214.18 & 4.2774 & 586.69 & 9.063 & 0.73447 & 1261385 & 528025 \\
\hline
\end{tabular}

Test of significance of correlation was done by comparing the computed values against tabular ' $r$ ' values given by (Fisher \& Yates 1963). Path analysis for estimating direct and indirect effects of traits in yield was performed using formula given by (Dewey \& Lu 1959). Rank Summation Index (RSI) to determine the rankings of the hybrids with regard to their overall performance according to (Mulamba \& Mock 1978) was summed as follows:

$$
\mathrm{RSI}=\Sigma \mathrm{Ri}^{\prime} \mathrm{S}
$$

Where, $\mathrm{Ri}=$ The rank of the means of each of the selected traits; RSI= Aggregate performance of the hybrid using the rankings of the selected traits.

\section{RESULTS}

Table 1. Means squares from analysis of variance for observed characters.

Note: $*$, ** Significant at $\mathrm{p}=0.05$ and $\mathrm{p}=0.01$ respectively.

The mean squares from analysis of variance for 10 observed traits of 25 sorghum hybrid are presented in table 1. It was observed that highly significant differences $(\mathrm{p}<0.01)$ and $(\mathrm{p}<0.05)$ among hybrids in all the 
characters except seedling emergence count. Significant variation was observed for hybrid by year interaction in panicle length and 1000-grain weight. However, there were no significant differences between years in all the characters studied.

Table 2. Mean performance of 25 sorghum hybrids evaluated for 10 agronomic characters.

\begin{tabular}{|c|c|c|c|c|c|c|c|c|c|c|}
\hline Hybrids & $\begin{array}{r}\text { Seedling } \\
\text { emergence } \\
\text { count }\end{array}$ & $\begin{array}{r}\text { Days to } \\
50 \% \\
\text { flowering } \\
\end{array}$ & $\begin{array}{r}\text { Day to } \\
95 \% \\
\text { maturity } \\
\end{array}$ & $\begin{array}{r}\text { Plant } \\
\text { height } \\
(\mathrm{cm})\end{array}$ & $\begin{array}{r}\text { Panicle } \\
\text { length } \\
(\mathrm{cm})\end{array}$ & $\begin{array}{r}\text { Panicle } \\
\text { weight } \\
(\mathrm{g})\end{array}$ & $\begin{array}{r}\text { 1000-grain } \\
\text { weight } \\
(\mathrm{g}) \\
\end{array}$ & $\begin{array}{r}\text { Panicle } \\
\text { diameter } \\
(\mathrm{cm})\end{array}$ & $\begin{array}{r}\text { Number of } \\
\text { seeds per } \\
\text { panicle }\end{array}$ & $\begin{array}{r}\text { Grain } \\
\text { yield } \\
\left(\mathrm{kg} \mathrm{ha}^{-1}\right) \\
\end{array}$ \\
\hline ICSA223 × CHOKWE-1 & $26.33 \mathrm{abc}$ & $82.00 \mathrm{a}$ & $110.00 \mathrm{a}$ & $138.26 \mathrm{ef}$ & 33.30abc & $99.33 \mathrm{ab}$ & $19.97 \mathrm{bc}$ & $5.79 a$ & 4942.33ab & $2980 \mathrm{ab}$ \\
\hline ICSA223 $\times$ CHOKWE-3 & $29.00 \mathrm{ab}$ & $.33 \mathrm{a}$ & $107.83 \mathrm{ab}$ & $142.80 \mathrm{def}$ & $35.00 \mathrm{ab}$ & $85.33 \mathrm{ab}$ & $21.73 \mathrm{abc}$ & $6.62 \mathrm{a}$ & 4084.00ab & $2560 \mathrm{ab}$ \\
\hline ICSA223 $\times$ ICSV400 & $14.00 \mathrm{abc}$ & $.66 a$ & $108.33 \mathrm{ab}$ & 152.40def & $35.70 \mathrm{a}$ & $114.96 \mathrm{ab}$ & $21.93 \mathrm{abc}$ & $6.83 a$ & $5294.33 \mathrm{ab}$ & $3449 \mathrm{ab}$ \\
\hline ICSA223 $\times$ MACIA-2 & $34.00 \mathrm{a}$ & $a$ & $108.00 \mathrm{ab}$ & $138.80 \mathrm{ef}$ & $33.83 \mathrm{ab}$ & $a b$ & $21.49 \mathrm{abc}$ & $4 a$ & $3 a b$ & $2747 \mathrm{ab}$ \\
\hline ICSA223 $\times$ MACIA-3 & $21.33 \mathrm{abc}$ & $.33 \mathrm{a}$ & $106.66 \mathrm{ab}$ & $133.40 \mathrm{f}$ & $34.43 \mathrm{ab}$ & $a b$ & $\mathrm{abc}$ & $52 a$ & $3 a b$ & $2971 \mathrm{ab}$ \\
\hline ICSA223 $\times$ PIRIRA-2- 1 & $23.33 \mathrm{abc}$ & $.66 a$ & $110.00 \mathrm{a}$ & $142.26 \mathrm{def}$ & $34.36 \mathrm{ab}$ & $85.30 \mathrm{ab}$ & & $99 a$ & $7 \mathrm{ab}$ & $2559 \mathrm{ab}$ \\
\hline ICSA223 × SRN15401 & $25.33 \mathrm{abc}$ & $70.66 \mathrm{a}$ & $100.33 b$ & $267.66 \mathrm{a}$ & $33.86 \mathrm{ab}$ & $96.36 \mathrm{ab}$ & $20.52 \mathrm{abc}$ & $5.16 a$ & $4551.00 \mathrm{ab}$ & $2891 \mathrm{ab}$ \\
\hline ICSA38 $\times$ CHOKWE- 1 & $17.00 \mathrm{abc}$ & $75.66 \mathrm{a}$ & $108.33 \mathrm{ab}$ & $178.06 \mathrm{~b}-\mathrm{f}$ & $37.80 \mathrm{a}$ & $104.76 \mathrm{ab}$ & & $7.16 \mathrm{a}$ & & $3143 \mathrm{ab}$ \\
\hline$\times$ CHOKWE-3 & $22.66 \mathrm{abc}$ & $.00 \mathrm{a}$ & $\mathrm{a}$ & $177.60 b-f$ & $33.33 \mathrm{abc}$ & & & $4 \mathrm{a}$ & & $a b$ \\
\hline$\times$ ICSV400 & $11.66 \mathrm{bc}$ & $3 \mathrm{a}$ & 108. & $202.66 b c$ & $3 \mathrm{a}$ & & & $9 \mathrm{a}$ & $a b$ & $67 \mathrm{a}$ \\
\hline $8 \times$ MACIA-2 & $19.66 \mathrm{abc}$ & & 104.6 & $173.53 b-f$ & $36.76 \mathrm{a}$ & $a b$ & & $7.12 \mathrm{a}$ & ab & $3382 \mathrm{ab}$ \\
\hline$\times$ MACIA-3 & $26.33 \mathrm{abc}$ & $00 \mathrm{a}$ & $0 \mathrm{a}$ & $166.00 \mathrm{~b}-\mathrm{f}$ & $34.06 \mathrm{ab}$ & $a b$ & & $5.62 \mathrm{a}$ & & $2248 a b$ \\
\hline$\times \mathrm{NIJ}-2$ & $19.33 \mathrm{abc}$ & $.00 \mathrm{a}$ & $110.00 \mathrm{a}$ & $157.33 \mathrm{~d}-\mathrm{f}$ & $37.43 a$ & $102.40 \mathrm{ab}$ & $22.39 \mathrm{abc}$ & $6.33 \mathrm{a}$ & $a b$ & $3072 \mathrm{ab}$ \\
\hline ICS & 13.6 & $0 \mathrm{a}$ & $0 \mathrm{a}$ & 186. & $6 a$ & & $a b c$ & & & \\
\hline $\mathrm{ICS}$ & abc & $.33 \mathrm{a}$ & $105.00 \mathrm{ab}$ & $273.73 a$ & $36.86 \mathrm{a}$ & $\mathrm{ab}$ & $a b c$ & $6.00 \mathrm{a}$ & $\mathrm{ab}$ & $2393 \mathrm{ab}$ \\
\hline ICSA502 $\times$ CHOKWE & $22.33 \mathrm{abc}$ & $78.00 \mathrm{a}$ & $104.33 \mathrm{ab}$ & $160.60 c-f$ & $28.93 b c$ & $98.93 \mathrm{ab}$ & $22.11 \mathrm{abc}$ & $5.70 \mathrm{a}$ & $0 \mathrm{ab}$ & $2968 \mathrm{ab}$ \\
\hline ICSA502 $\times$ ICSV400 & $24.33 \mathrm{abc}$ & $.33 \mathrm{a}$ & $106.66 \mathrm{ab}$ & $176.00 \mathrm{~b}-\mathrm{f}$ & $33.83 \mathrm{ab}$ & $99.00 \mathrm{ab}$ & $20.90 \mathrm{abc}$ & $5.83 a$ & $7 \mathrm{ab}$ & $2970 \mathrm{ab}$ \\
\hline $2 \times$ MACIA-2 & $14.66 \mathrm{abc}$ & & & $151.33 \mathrm{~d}-\mathrm{f}$ & & & & & & \\
\hline $02 \times$ CHOKWE-3 & $6.33 c$ & $3 a$ & 106 & $179.53 b-e$ & $32.50 \mathrm{abc}$ & $3 a b$ & $a b$ & $5 \mathrm{a}$ & $a b$ & $7 \mathrm{ab}$ \\
\hline ICSA89002 × PIRIRA-2-1 & $23.33 \mathrm{abc}$ & $33 \mathrm{a}$ & $110.00 \mathrm{a}$ & $172.73 b-f$ & $32.10 \mathrm{abc}$ & $111.50 \mathrm{ab}$ & $20.48 \mathrm{abc}$ & $5.74 a$ & $.33 \mathrm{a}$ & $3345 \mathrm{ab}$ \\
\hline ICSA89003 × CHOKWE-1 & $6.00 \mathrm{c}$ & $.66 \mathrm{a}$ & $110.00 \mathrm{a}$ & $179.53 b-e$ & $32.76 a b c$ & 98.33ab & $23.57 \mathrm{abc}$ & $6.04 \mathrm{a}$ & $4230.33 \mathrm{ab}$ & $2950 \mathrm{ab}$ \\
\hline ICSA $89003 \times$ ICSV400 & $20.00 \mathrm{abc}$ & $33 \mathrm{a}$ & $106.66 \mathrm{ab}$ & $207.93 b$ & $32.90 \mathrm{abc}$ & $76.83 \mathrm{ab}$ & $27.51 \mathrm{ab}$ & $6.08 \mathrm{a}$ & $7 \mathrm{ab}$ & $2305 \mathrm{ab}$ \\
\hline ICSA89003 × MACIA-3 & $12.00 \mathrm{bc}$ & $74.00 \mathrm{a}$ & $102.33 \mathrm{ab}$ & $173.06 b-f$ & $34.60 \mathrm{ab}$ & $96.26 \mathrm{ab}$ & $24.94 \mathrm{abc}$ & $6.95 \mathrm{a}$ & $3896.33 \mathrm{ab}$ & $2888 \mathrm{ab}$ \\
\hline ICSA89003 × NIJ-2 & $19.66 \mathrm{abc}$ & $75.66 \mathrm{a}$ & $106.66 \mathrm{ab}$ & $209.80 b$ & $27.10 \mathrm{c}$ & $60.00 \mathrm{~b}$ & $29.94 \mathrm{a}$ & $4.79 a$ & $1994.33 b$ & $1800 \mathrm{~b}$ \\
\hline ICSA89003 × SRN15401 & $14.00 \mathrm{abc}$ & $72.33 \mathrm{a}$ & $104.00 \mathrm{ab}$ & $267.00 \mathrm{a}$ & $34.66 \mathrm{ab}$ & $67.43 \mathrm{ab}$ & $30.06 \mathrm{a}$ & $5.78 \mathrm{a}$ & 2258.67ab & $2023 \mathrm{ab}$ \\
\hline
\end{tabular}

Note: Means in a column with the same letter (s) are not significantly different by Tukey's test $(\mathrm{P}=0.05)$

Mean performance of the 25 sorghum hybrids evaluated for ten agronomic characters is presented in table 2. The highest significant mean for seedling emergence counts were obtained from hybrid ICSA223 $\times$ MACIA-2 (34.00) while the least mean for seedling emergence count was recorded in ICSA89003 $\times$ CHOKWE-1 (6.00). There were no significant differences for number of days to 50\% flowering in 2016. Number of days to $95 \%$ maturity showed ICSA223 $\times$ CHOKWE-1, ICSA223 $\times$ PIRIRA-2-1, ICSA38 $\times$ CHOKWE-3, ICSA38 $\times$ MACIA-3, ICSA38 $\times$ NIJ-2, 1CSA38 $\times$ PIRIRA-2-1, ICSA89002 $\times$ PIRIRA-2-1 and ICSA89003 $\times$ CHOKWE1 were not significantly different in 2016 while ICSA223 $\times$ SRN15401 recorded the least (100.33). ICSA38 $\times$ SRN15401 had the highest plant height in $2016(273.73 \mathrm{~cm})$ while ICSA223 $\times$ MACIA-3 recorded the least height $(133.40 \mathrm{~cm})$ among other hybrids. The longest panicle length was observed in hybrid ICSA38 $\times$ CHOKWE-1 $(37.80 \mathrm{~cm})$ while the shortest was $27.10 \mathrm{~cm}$ for hybrid ICSA89003 $\times$ NIJ-2 in year 2016. ICSA38 $\times$ ICSV400 recorded significantly highest mean for panicle weight $(138.90 \mathrm{~g})$ while ICSA89003 $\times$ NIJ-2 had the lowest panicle weight $(60.00 \mathrm{~g})$ for panicle weight in 2016. A significant difference was observed among the hybrid for 1000-grain weight in 2016, ICSA89003 $\times$ SRN15401 recorded the highest mean for 1000-grain weight $(30.06 \mathrm{~g})$ while ICSA223 $\times$ PIRIRA-2-1 had the lowest $(16.79 \mathrm{~g})$ mean for 1000-grain weight. There were no significant differences between the panicle diameter among the hybrids in 2016. ICSA38 $\times$ PIRIRA-2-1 was observed to have the highest mean for number of seeds per panicle $(5862.33)$ while ICSA89003 $\times$ NIJ-2 had the lowest (1994.33). In 2016, ICSA38 $\times$ ICSC400 was highly significant and recorded the highest grain yield $\left(4167 \mathrm{~kg} \mathrm{ha}^{-1}\right)$ while the lowest was recorded by ICSA89003 $\times$ NIJ-2 $\left(1800 \mathrm{~kg} \mathrm{ha}^{-1}\right)$.

Estimates of genotypic coefficient of variation, phenotypic coefficient of variation, heritability, genetic advance and genetic gain for ten agronomic characters of 25 sorghum hybrids are presented in table 3 . The genotypic coefficient of variation (GCV) was observed to be lower than phenotypic coefficient of variation (PCV) for all the characters under study. GCV for seedling emergence count, number of days to $95 \%$ maturity, panicle weight, 1000-grain weight, and grain yield was $19.90 \%, 1.56 \%, 14.47 \%, 7.60 \%$ and $14.48 \%$ respectively to PCV seedling emergence count (39.82\%), number of days to $95 \%$ maturity (3.12\%), panicle weight $(28.94 \%), 1000$-grain weight $(15.20 \%)$ and grain yield $(28.96 \%)$. Heritability estimates varied from 
$20.43 \%$ for panicle diameter to $25.46 \%$ for plant height. Genetic advance was relatively low for seedling emergence count (3.94) showing uniformity of seed germination, number of days to 50\% flowering (2.73), number of days to $95 \%$ maturity (1.72), plant height (8.58), panicle length (1.24), 1000-grain weight (1.82), panicle diameter (0.40) and panicle weight (14.43) while other traits had comparatively high means. In 2016, the highest expected genetic gain was (20.47\%) for seedling emergence count, number of seeds per panicle (16.00\%), grain yield (14.91\%) and panicle weight (14.90\%) while other traits had low genetic gain.

Table 3. Coefficient of variation, heritability, genetic advance and expected genetic gain estimates for yield and its components of the 25 hybrids sorghum.

\begin{tabular}{lrrrrr}
\hline Characters & $\begin{array}{r}\text { Genotypic } \\
\text { coefficient of } \\
\text { variation (GCV) }(\%)\end{array}$ & $\begin{array}{r}\text { Phenotypic } \\
\text { coefficient of }\end{array}$ & $\begin{array}{r}\text { Heritability } \\
\text { variation (PCV) }(\%)\end{array}$ & $\begin{array}{r}\text { Genetic } \\
\text { advance }\end{array}$ & $\begin{array}{r}\text { Expected } \\
\text { genetic gain } \\
(\boldsymbol{\%})\end{array}$ \\
\hline Seedling emergence count & 19.90 & 39.82 & 25.00 & 3.94 & 20.47 \\
Days to 50\% flowering & 3.36 & 6.74 & 24.95 & 2.73 & 3.46 \\
Days to 95\% maturity & 1.56 & 3.12 & 24.97 & 1.72 & 1.60 \\
Plant height (cm) & 4.57 & 9.07 & 25.46 & 8.58 & 4.75 \\
Panicle length (cm) & 3.54 & 7.09 & 25.00 & 1.24 & 3.65 \\
Panicle weight (g) & 14.47 & 28.94 & 25.00 & 14.43 & 14.90 \\
1000 grain weight (g) & 7.60 & 15.20 & 25.00 & 1.82 & 7.80 \\
Panicle diameter (cm) & 7.06 & 15.62 & 20.43 & 0.40 & 6.48 \\
Number of seeds per panicle & 15.57 & 31.14 & 25.00 & 689.64 & 16.00 \\
Grain yield (kg ha') & 14.48 & 28.96 & 25.00 & 433.13 & 14.91 \\
\hline
\end{tabular}

Table 4. Correlation coefficients among evaluated characters of the hybrids.

\begin{tabular}{lrrrrrrrr}
\hline Characters & $\begin{array}{r}\text { Days to } \\
\mathbf{9 5 \%} \\
\text { maturity }\end{array}$ & $\begin{array}{r}\text { Plant } \\
\text { height } \\
(\mathbf{c m})\end{array}$ & $\begin{array}{r}\text { Panicle } \\
\text { length } \\
(\mathbf{c m})\end{array}$ & $\begin{array}{r}\text { Panicle } \\
\text { weight } \\
(\mathbf{c m})\end{array}$ & $\begin{array}{r}\text { 1000 grain } \\
\text { weight } \\
(\mathbf{g})\end{array}$ & $\begin{array}{r}\text { Panicle } \\
\text { diameter } \\
(\mathbf{c m})\end{array}$ & $\begin{array}{r}\text { Number of } \\
\text { seeds per } \\
\text { panicle }\end{array}$ & $\begin{array}{r}\text { Grain } \\
\text { yield } \\
\left(\mathbf{k g ~ h a}^{-1}\right)\end{array}$ \\
\hline Day to 50\% flowering & $0.79^{* *}$ & $-0.53^{* *}$ & $0.22^{*}$ & $0.21^{*}$ & $-0.56^{* *}$ & 0.12 & $0.33^{* *}$ & 0.21 \\
Days to 95\% maturity & & $-0.52^{* *}$ & 0.13 & 0.18 & $-0.38^{* *}$ & 0.04 & $0.36^{* *}$ & 0.18 \\
Plant height $(\mathrm{cm})$ & & & 0.05 & $-0.28^{*}$ & $-0.53^{* *}$ & $-0.46^{* *}$ & $-0.49^{* *}$ & $-0.28^{* *}$ \\
Panicle length (cm) & & & & $0.36^{* *}$ & -0.13 & $0.57^{* *}$ & $0.27^{* *}$ & $0.36^{* *}$ \\
Panicle weight (cm) & & & & & $-0.32^{* *}$ & $0.38^{* *}$ & $0.89^{* *}$ & $0.98^{* *}$ \\
1000 grain weight (g) & & & & & & -0.07 & $-0.76^{* *}$ & $-0.32^{* *}$ \\
Panicle diameter (cm) & & & & & & & $0.28^{* *}$ & $0.38^{* *}$ \\
Number of seeds per panicle & & & & & & & & $0.84^{* *}$ \\
\hline
\end{tabular}

Note: *, ** Significant at $\mathrm{p}=0.05$ and $\mathrm{p}=0.01$ respectively.

The correlation coefficients among characters are presented in table 4. The correlation result revealed that number of days to $50 \%$ flowering had positive and significant correlation with number of days to $95 \%$ maturity $(\mathrm{r}=0.79)$ and number of seeds per panicle $(\mathrm{r}=0.33)$ but had negative and significant correlation with plant height $(r=-0.53)$ and 1000-grain weight $(r=-0.56)$. The number of days to $95 \%$ maturity had negative and significantly correlated with plant height and 1000-grain weight $(r=-0.52$ and -0.38$)$ but positively and significantly correlated with number of seed per panicle (0.36). Plant height was negatively and significantly correlated to panicle weight $(r=-0.28)$, panicle diameter $(r=-0.46)$, number of seeds per panicle $(r=-0.49)$ and grain yield $(r=-0.28)$ but had positive significant correlation with 1000-grain weight $(r=0.53)$. Panicle length had positive and significant correlation with panicle weight, panicle diameter, number of seeds per panicle and grain yield ( $\mathrm{r}=0.36,0.57,0.27$ and 0.36 , respectively). Panicle weight had negative and significant correlation with 1000-grain weight $(\mathrm{r}=-0.32)$ but positive correlations was recorded in panicle diameter, number of seeds per panicle and grain yield $(r=0.38,0.89$ and 0.98$) .1000$-grain weight had negative but significant correlation with number of seeds per panicle and grain yield $(r=-0.76$ and -0.32$)$. Panicle diameter had positive significant correlation with number of seed per panicle $(r=0.28)$ and grain yield $(r=0.38)$. Nevertheless, number of seeds per panicle had positive significant correlation with grain yield $(r=0.84)$.

Path analysis depicted the strength of contributions of all independent variables understudy on the grain yield (Table 5). Panicle weight had the highest positive direct effect (0.961) on grain yield followed by days to $50 \%$ maturity (0.046) and the number of seeds per panicle (0.014). On the other hand plant height showed high negative direct effect on grain yield with (-0.014). Panicle length had low positive direct effect on grain yield (0.010). Its positive indirect effect was through seedling emergence count $(0.001)$, number of days to $95 \%$ maturity (0.031), panicle weight (0.436), panicle diameter (0.003) and number of seeds per panicle (0.004), whereas its indirect effect was negative through, number of days to $50 \%$ flowering $(-0.018)$, plant height (- 
$0.002)$ and 1000 grain weight (-0.000). Panicle weight had high positive direct effect on grain yield (0.961). Its positive indirect effect was through seedling emergence count (0.009), number of days to $95 \%$ maturity (0.019), plant height (0.008), panicle diameter $(0.002)$ and number of seeds per panicle $(0.013)$, whereas its indirect effect was negative in the number of days to $50 \%$ flowering $(-0.018)$. The number of seeds per panicle had positive direct effect on grain yield (0.014). Its positive indirect effect was through number of days to $95 \%$ maturity (0.030), plant height (0.009), panicle length (0.006), panicle weight $(0.857)$ and panicle diameter $(0.001)$, whereas its indirect effect was negative through seedling emergence count $(-0.004)$, number of days to $50 \%$ flowering (-0.018) and 1000 grain weight (-0.002).

Table 5. Path coefficient analysis of grain yield of hybrids sorghum.

\begin{tabular}{|c|c|c|c|c|c|c|c|c|c|}
\hline Characters & $\begin{array}{r}\text { Seedling } \\
\text { emergence } \\
\text { count }\end{array}$ & $\begin{array}{r}\text { Days to } \\
50 \% \\
\text { flowering }\end{array}$ & $\begin{array}{r}\text { Days to } \\
95 \% \\
\text { maturity }\end{array}$ & $\begin{array}{r}\text { Plant } \\
\text { height } \\
(\mathrm{cm})\end{array}$ & $\begin{array}{r}\text { Panicle } \\
\text { length } \\
(\mathrm{cm})\end{array}$ & $\begin{array}{r}\text { Panicle } \\
\text { weight } \\
\text { (g) }\end{array}$ & $\begin{array}{r}\text { 1000-grain } \\
\text { weight } \\
(\mathrm{g})\end{array}$ & $\begin{array}{r}\text { Panicle } \\
\text { diameter } \\
(\mathrm{cm})\end{array}$ & $\begin{array}{r}\text { Number of } \\
\text { seeds per } \\
\text { panicle }\end{array}$ \\
\hline Seedling emergence count & -0.021 & -0.018 & 0.023 & 0.005 & -0.001 & -0.415 & -0.001 & 0.000 & 0.002 \\
\hline Days to $50 \%$ flowering & -0.021 & -0.018 & 0.046 & 0.014 & 0.010 & 0.961 & -0.002 & 0.003 & 0.014 \\
\hline Days to $95 \%$ maturity & -0.011 & -0.018 & 0.046 & 0.009 & 0.005 & 0.408 & -0.001 & -0.000 & 0.009 \\
\hline Plant height $(\mathrm{cm})$ & 0.007 & 0.018 & -0.029 & -0.014 & 0.001 & -0.537 & 0.001 & -0.003 & -0.009 \\
\hline Panicle length $(\mathrm{cm})$ & 0.001 & -0.018 & 0.013 & -0.002 & 0.010 & 0.436 & -0.000 & 0.003 & 0.004 \\
\hline Panicle weight $(\mathrm{g})$ & 0.009 & -0.018 & 0.019 & 0.008 & 0.009 & 0.961 & -0.001 & 0.002 & 0.013 \\
\hline 1000 grain weight $(\mathrm{g})$ & 0.011 & 0.018 & -0.029 & -0.008 & -0.003 & -0.752 & 0.002 & -0.001 & -0.013 \\
\hline Panicle diameter $(\mathrm{cm})$ & -0.003 & -0.018 & -0.006 & 0.011 & 0.018 & 0.625 & -0.000 & 0.003 & 0.003 \\
\hline Number of seeds per panicle & -0.004 & -0.018 & 0.030 & 0.009 & 0.006 & 0.857 & -0.002 & 0.001 & 0.014 \\
\hline
\end{tabular}

Note: Direct (diagonal) and indirect (out of diagonal)

Table 6 shows the rank summation index. Hybrid ICSA38 $\times$ ICSV400 had the best performance with a mean rank of 4.8. It was followed by ICSA38 $\times$ PIRIRA-2-1 with a mean rank of 6.6. Hybrid ICSA89003 $\times$ NIJ-2 and ICSA223 $\times$ PIRIRA-2-1 had the poorest performance with the means of $(18.1,16.8)$ respectively.

Table 6. Mean ranking index of 25 sorghum hybrids evaluated for yield and yield components.

\begin{tabular}{|c|c|c|c|c|c|c|c|c|c|}
\hline HYBRIDS & $\begin{array}{r}\text { Days to } \\
50 \% \\
\text { flowering }\end{array}$ & $\begin{array}{r}\text { Plant } \\
\text { height } \\
(\mathbf{c m})\end{array}$ & $\begin{array}{r}\text { Panicle } \\
\text { length } \\
(\mathrm{cm})\end{array}$ & $\begin{array}{r}\text { Panicle } \\
\text { weight } \\
(\mathrm{g})\end{array}$ & $\begin{array}{r}\text { 1000-grain } \\
\text { weight } \\
(\mathrm{g})\end{array}$ & $\begin{array}{r}\text { Number of } \\
\text { seed per } \\
\text { panicle } \\
\end{array}$ & $\begin{array}{r}\text { Grain } \\
\text { yield } \\
\left(\mathrm{kg} \mathrm{ha}^{-1}\right) \\
\end{array}$ & $\begin{array}{c}\text { Total } \\
\text { rank }\end{array}$ & 埇 \\
\hline ICSA223 × CHOKWE-1 & $81.67(6)$ & $137.32(24)$ & $33.52(17)$ & $98.45(13)$ & $19.63(24)$ & $4980.17(6)$ & $2953.5(13)$ & 103 & 16 \\
\hline ICSA223 × CHOKWE-3 & $81.84(4)$ & $143.15(21)$ & $34.88(8)$ & 86.60(19) & $22.04(15)$ & $4068.50(18)$ & 2598.0(19) & 104 & 17 \\
\hline ICSA223 × ICSV400 & $78.68(14)$ & $150.97(20)$ & $35.72(6)$ & $114.9(3)$ & $22.53(12)$ & $5171.50(4)$ & $3447.0(3)$ & 62 & 5 \\
\hline ICSA223 $\times$ MACIA-2 & $81.00(7)$ & $138.48(23)$ & $33.75(10)$ & $91.90(18)$ & 21.51(16) & $4415.83(15)$ & $2757.0(18)$ & 107 & 18 \\
\hline ICSA223 × MACIA-3 & $81.83(5)$ & $133.45(25)$ & $34.47(12)$ & $99.60(10)$ & $21.05(20)$ & $(9)$ & $2988.0(10)$ & 91 & 11 \\
\hline ICSA223 × PIRIRA-2-1 & $79.17(13)$ & $142.32(22)$ & $34.25(13)$ & $84.75(20)$ & $(25)$ & (5) & $2542.5(20)$ & 118 & 24 \\
\hline ICSA223 × SRN15401 & $73.33(24)$ & $267.40(3)$ & $33.90(15)$ & $96.07(15)$ & $20.51(23)$ & $4516.17(12)$ & $2882.0(15)$ & 87 & 9 \\
\hline ICSA38 × CHOKWE- 1 & $76.17(21)$ & $177.80(10)$ & $37.73(2)$ & $104.62(7)$ & $34(10)$ & 458 & $3138.5(7)$ & 67 & 6 \\
\hline ICSA38 $\times$ CHOKWE-3 & $80.83(8)$ & $177.48(11)$ & $33.25(18)$ & $94.83(17)$ & 21.24(18) & $4472.50(13)$ & $2845.0(17)$ & 102 & 15 \\
\hline ICSA38 $\times$ ICSV400 & $79.67(11)$ & $203.08(6)$ & $35.78(5)$ & $139.47(1)$ & $24.93(7)$ & $5602.67(3)$ & $4184.0(1)$ & 34 & 1 \\
\hline ICSA38 $\times$ MACIA-2 & 80.6 & $173.32(13)$ & $36.89(3)$ & $112.18(5)$ & $27.91(4)$ & $4112.83(17)$ & $3365.5(4)$ & 55 & 3 \\
\hline ICSA38 $\times$ MACIA-3 & $82.50(3)$ & $166.00(16)$ & $34.10(14)$ & $74.82(23)$ & $22.57(11)$ & $3317.17(21)$ & $2244.5(23)$ & 111 & 21 \\
\hline ICSA38 $\times$ NIJ-2 & & & & & & & (8) & 61 & 4 \\
\hline ICSA38 $\times$ PIRIRA-2-1 & $79.83(10)$ & $185.27(7)$ & $35.62(7)$ & $124.93(2)$ & 21.32(17) & (1) & $3748.0(2)$ & 46 & 2 \\
\hline ICSA38 $\times$ SRN15401 & $79.50(12)$ & $272.55(1)$ & $36.88(4)$ & $79.88(21)$ & $25.94(6)$ & $3075.33(22)$ & $2396.5(21)$ & 87 & 9 \\
\hline ICSA502 × CHOKWE-1 & $78.34(17)$ & $159.77(17)$ & $28.98(24)$ & $98.58(12)$ & $22.11(14)$ & $4428.50(14)$ & $2957.5(12)$ & 110 & 22 \\
\hline ICSA502 $\times$ ICSV400 & $78.17(18)$ & $175.22(12)$ & $33.73(16)$ & $99.27(11)$ & $20.94(21)$ & $4963.50(8)$ & $2978.0(11)$ & 97 & 14 \\
\hline ICSA502 $\times$ MACIA-2 & $78.33(16)$ & $151.70(19)$ & $31.37(23)$ & $105.22(6)$ & 21.23(19) & & $3156.5(6)$ & 96 & 13 \\
\hline ICSA89002 × CHOKWE-3 & $73.17(25)$ & $178.45(8)$ & $32.58(21)$ & $101.98(9)$ & $29.41(3)$ & $3486.33(20)$ & $3059.5(9)$ & 95 & 12 \\
\hline ICSA89002 × PIRIRA-2-1 & $78.67(15)$ & $172.90(14)$ & $32.22(22)$ & $111.43(4)$ & $20.81(22)$ & $5672.17(2)$ & $3343.0(5)$ & 84 & 8 \\
\hline ICSA89003 × CHOKWE-1 & 83.5 & $178.37(9)$ & $32.73(19)$ & $98.10(14)$ & & $4263.8 ?$ & $2943.0(14)$ & 82 & 7 \\
\hline ICSA89003 × ICSV400 & $77.83(19)$ & $208.22(4)$ & $32.70(20)$ & $77.22(22)$ & $27.21(5)$ & $2802.50(23)$ & $2316.5(22)$ & 115 & 23 \\
\hline ICSA $89003 \times$ MACIA-3 & $75.00(22)$ & $172.82(15)$ & $34.63(11)$ & $96.05(16)$ & 24.81(8) & $3909.83(19)$ & $2881.5(16)$ & 107 & 18 \\
\hline ICSA89003 × NIJ-2 & $76.83(20)$ & $207.80(5)$ & $27.05(25)$ & $59.73(25)$ & $29.99(2)$ & $1983.50(25)$ & $1792.0(25)$ & 127 & 25 \\
\hline ICSA89003 $\times$ SRN15401 & $74.33(23)$ & $267.80(2)$ & $34.80(9)$ & $67.78(24)$ & $30.62(1)$ & $2228.67(24)$ & $2033.5(24)$ & 107 & 18 \\
\hline
\end{tabular}

\section{DISCUSSION}

The variation observed among the hybrids for the agronomic traits may be attributed to the genetic makeup of the hybrid parents. Various researchers have reported significant variation in sorghum hybrid (Fayeun et al. 2012, Arunkumar 2013, Menezes et al. 2015, Eniola 2019). Among the hybrids, ICSA38 × ICSA400, ICSA38 × www.tropicalplantresearch.com 
PIRIRA-2-1 had the highest mean for panicle weight and number of seeds per panicle, respectively. While these hybrids can be recommended for utilization, the parents can be recommended for further improvement; and probably tested in various agro-ecological zones for yield potential, pest and disease reaction and adaptation for adoption.

The phenotypic coefficient of variation was higher than genotypic coefficients of variation for all corresponding traits indicating some contribution of the environment in the expression of the characters. Higher phenotypic coefficient of variation has being reported in different crops like soybean and fluted pumpkin for seedling traits (Mohammadi \& Pourdad 2009, Fayeun et al. 2016). Broad sense heritability was moderate for most characters considered and low genetic advance was recorded for most of the traits except number of seeds per panicle and grain yield. This suggests the moderate influence of the environment on most of the traits under study; and may be relatively suitable in many ecological zone for propagation by farmer and sorghum stakeholders to boost production. Selection will also be possible in the desired direction. Fayeun et al. (2017) equally reported in extra-early maize hybrids moderate effect of environment. The phenomenon, therefore, implies continuous evaluation of hybrid sorghum just like in maize for genotypic and environmental expression for identifying adaptable genotypes.

Knowledge of correlation between traits of economic importance are not only of interest from theoretical consideration of quantitative inheritance of characters, but of practical value since selection is usually concerned with changing two or more traits simultaneously (Prasuna 2012). Johnson et al. (1955) explained that where the genetic correlation coefficients are high, there is a strong heritability between characters. This means that selection for these characters can be carried out irrespective of the locations. The low values of the correlation coefficient obtained may slow down the progress from selection. High negative values of correlation coefficients were obtained for some characters. This showed that selection for some of these characters would affect each other in the opposite direction as earlier suggested by Bello et al. (2001).

The correlation coefficient helps in determining the direction of selection and number of characters to be considered in improving the grain yield. So it is a matter of great importance to the plant breeders to find out of the characters that are correlated with yield and also how they are associated with themselves. From this study, grain yield shows positive and significant correlation with panicle length, panicle weight, panicle diameter and number of seeds per panicle. Previous workers have also reported sorghum grain yield as a function of number of seed per panicle (Aba \& Obilana 1994, Eniola 2019), and panicle weight (Aba \& Zaria 2000, Eniola 2019). Thus, it was revealed from the present study that the traits like panicle length, panicle weight and number of seeds per panicle are of great importance in yield components. Hence, due consideration should be given to these characters, while planning a breeding strategy for increased grain yield.

Path coefficient analysis measures the direct influence of one variable upon the other and permits separation of correlation coefficient into components of direct and indirect effects. Partitioning of total correlation into direct and indirect effects provides actual information on the contribution of characters and thus forms the basis for selection to improve yield. Hence genotypic correlations were partitioned into direct and indirect effects to know the relative importance of the components.

In this study, it was observed that number days to 95\% maturity, panicle length, panicle weight, 1000-grain weight, panicle diameter and number of seeds per panicle had positive and direct effect on grain yield while panicle weight had the highest positive direct effect on grain yield indicating the importance of these characters to grain yield. These traits should be considered simultaneously when developing selection criteria for grain yield improvement in sorghum. Several researchers, (Jindla \& Gill 1984, Singh \& Govila 1989, Bidinger et al. 1993, Eniola 2019) also found similar results in sorghum. It is inferred from correlation and path analysis that panicle weight which recorded significant positive correlation co-efficient and also had high positive direct effect that might be regarded as the prime character. This indicates that panicle weight is the most important trait influencing the grain yield. Thus, selection for heavy panicle is a pre-requisite to attaining higher grain yield in sorghum. Next to it is number of seeds per panicle which showed high positive direct effect as well as high correlation with grain yield per plant. Its indirect effect through panicle weight has also been high among all traits that contributed significantly to grain yield.

The ranking summation index (RSI) is a tool that allows the plant breeders to select the genotypes with the best performance in terms of yield and its components in the two or more seasons of testing (Harriman et al. 2012). The hybrids that showed better performance in terms of yield and traits that contribute to it include ICSA38 $\times$ ICSV400, ICSA38 × PIRIRA-2-1 and ICSA38 × MACIA-2. 


\section{CONCLUSION}

There is a potential of increased sorghum yields through the use of hybrids. Variation existed among the hybrids in a number of traits. These were number of seeds per panicle, panicle length and panicle weight of sorghum. Also, there existed significant correlation between panicle length, panicle weight and number of seeds per panicle. Consequently, selection for any of these traits could lead to indirect selection for improved grain yield. Simultaneous selection for these characters can be made for the improvement of grain yield. The exploitation of these traits provides an excellent opportunity to increase the performance of sorghum in terms of high yield and yield potential.

\section{REFERENCES}

Aba DA \& Obilana AT (1994) Correlations in a Mass selected population of sorghum. East Africa Agriculture Forest Journal 60(1): 45-50.

Aba DA \& Zaria AA (2000) Correlation and path analysis for some characters contributing to grain yield $\mathrm{n}$ sorghum. Polymath 1(1): 41-43.

Akintayo I \& Sedgo J (2003) Towards sustainable sorghum production and utilization in West and Central African. Proceedings of a Technical Workshop of the West and Central Africa Sorghum Research Network. International Crops Research Institute for the Semi-Arid Tropics, pp. 162. [ISBN 92-9066-4330-9]

Alade OD, Fayeun LS \& Obilana AB (2017) Morphological Evaluation of Long Season Sorghum Accessions in Akure, South West Nigeria. Proceeding of the $3^{\text {rd }}$ Annual Conference of Association of Seed Scientists of Nigeria (ASSN), pp. 62-69.

Arunkumar B (2013) Genetic variability, character association and path Analysis studies in sorghum (Sorghum bicolor L. Moench). Agricultural Research Station, Raddewadgi, Gulabarga, (Karnataka): International Quartely Journal of Life Sciences 8(4): 1485-1488.

Ayeni A (2011) Malaria Morbidity in Akure, Southwest, Nigeria: A Temporal Observation in a Climate Change Scenario. Trends in Applied Science Research 6: 488-494.

Bello D, Kadams AM \& Simon SY (2001) Correlation and Path Coefficient analysis of grain yield and its components in Sorghum. Nigerian Journal of Tropical Agriculture 3: 4-9.

Bidinger FR, Alagarswamy G, \& Rai KN (1993) Use of grain number components as selection criteria in pearl millet. Crop Improvement 20: 21-26.

Dasai BB, Inamdar DG, Chavan VD \& Naik RM (1992) Proximate Composition and Protein fractions of some promising sorghum cultivars. Journal of Maharashtra Agricultural Universities 17: 307-308.

Dewey DR \& Lu KH (1959) A correlation and path coefficient analysis of grain yield in some types of winter sorghum. Sorghum News Letter 21: 23.

Elrod SL \& Stanfield WD (2002) Genetic variance and heritability, Encycopaedia of Genetics, Vol I \& II. Pentagon Press.

Eniola AO (2019) Evaluation of Grain Yield and Yield Components of Sorghum (Sorghum bicolor (L.) Moench.) Hybrids in Akure South West Nigeria. (M. Tech. (Agric.) Thesis). Federal University of Technology, Akure, Nigeria.

FAO (2004) Food and Agriculture Organization of the United Nations. Sorghum and Millet production and nutrition. Chapter 2. Available from: www.fao.org/docrep.pp.2. (accessed: 10 Apr. 2017).

FAO (2010) Food and Agricultural Organization of United Nation. Rome. Statistic Division.

Fayeun LS, Adeseun DE, Mogaji BO \& Eniola OA (2017) Dry Season Evaluation of Extra-Early Maize Hybrids for Growth and Yield in a Rainforest Agro-Ecological Zone. Applied Tropical Agriculture 22(2): $73-78$

Fayeun LS, Lateef A, Olusegun A, Jide U \& Edith U (2016) Estimates of Genetic Variability for Seedling Traits in Fluted Pumpkin (Telfairia occidentalis Hook. F); Journal of Plant Breeding and Biotechnology 4(2): 262270.

Fayeun LS, Odiyi AC, Makinde SCO \& Aiyelari OP (2012) Genetic Variability and Correlation Studies in the Fluted Pumpkin (Telfairia occidentalis Hook. F.). Journal of Plant Breeding and Crop Science 4(10): 156160.

Fisher R \& Yates F (1963) Statistical Tables for Biological, Agricultural and Medical Research, $6^{\text {th }}$ edition. Oliver and Boyd Publisher, Edinburg, pp. 48-62.

FMARD (2011) Sorghum Transformation Action Plan. Federal Ministry of Agriculture and Rural Development, Abuja Nigeria. 
Harriman JC, Ngwuta AA, Onyishi GC, Nwadinobi CA, Orji JO, Ndulue NK, Ogu CE, Okoye AI \& Njoku G (2012) Response of Yellow Yam (Dioscorea cayenensis) to shoot growth phytohormones on the tissue and organ morphogenesis. New York Science Journal 7(11): 16-24.

IPGRI (1993) Descriptors for Sorghum (Sorghum bicolor (L) Moench). International board for plant genetic resources, Rome, Italy.

Jindla LN \& Gill KS (1984) Inter-relationship of yield and its component characters in pearl millet. Crop Improvement 11: 43-46.

Johnson HE, Robinson HF \& Comstock RE (1955) Estimates of genetic and Environmental viability of soybean. Agronomy Journal 47: 314-318.

Menezes CB, Ticona-Benavente CA, Tardin FD \& Cardoso MJ (2015) Selection indices to identify drought tolerant grain sorghum cultivars. Genetics and Molecular Research 13: 9817-9827.

Mohammadi R \& Pourdad SS (2009) Estimation, interrelationships and repeatability of genetic variability parameters in spring safflower using multi-environment trail data. Euphytica 165: 313-324.

Mohammed DT \& Ahmed FF (2015) The Effect of Insurgency on Borno State Economy (2008 - Oct. 2014). Journal of Economics and Sustainable Development 6(16): 94-102.

Mohammed MI \& Talib NH (2008) Heterosis and combining ability for quality traits in fodder sorghum. Australian Journal of Basic Applied Science 2: 99-104.

Mulamba NN \& Mock JJ (1978) Improvement of yield potential of the Eto Blanco maize (Zea mays L.) population by breeding for plant traits. Egyptian Journal of Genetics and Cytology 7: 40-51.

Obilana AB (2004) Sorghum Breeding Research in Africa. In: Bantilan MCS , Deb UK, Gowda CLL, Reddy BVS, Obilana AB \& Evenson RE (eds) Sorghum genetic enhancement - Research process, Dissemination and Impacts. International Crops Research Institute for the Semi-Arid Tropics, Andhra Pradesh, India, pp. 105-130.

Paterson IL (2009) The Sorghum bicolor genome and the diversification of grasses. Nature 457: 551-556.

Prasuna RC (2012) Studies on Heterosis and Combining Ability for Yield Components in grain sorghum (Sorghum bicolor L. Moench) (M.Sc. Thesis). Acharya NG. Ranga Agricultural University. Rajendranagar, Hyderabad, 140 p.

Singh B \& Govila OP (1989) Inheritance of grain size in pearl millet. Indian Journal of Genetics and Plant Breeding 49: 63-65.

Singh RK \& Chaudhary BD (1985) Biometrical Method in Quantitative Genetics Analysis. Kalyani Publishers, New Delhi.

Siva-Subramanian S \& Menon M (1973) Heterosis and inbreeding depression in rice. Madras Agricultural Journal 60: 1139.

USDA (2017) United States Department of Agriculture. World's Sorghum Production. National Agricultural Statistics Service (NASS), Agricultural Statistics Board. 